\title{
The church and the parachurch: Can the two dialogue in order to agree?
}

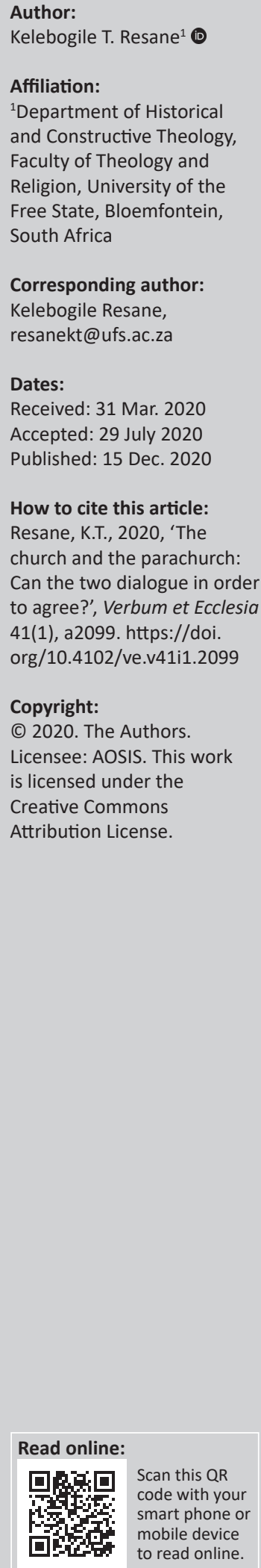

This article surveys the ongoing tensions between the church and the parachurch. It starts by defining the parachurch ministries as organisations that work outside and across denominations, and seek to come alongside the church and specialise in activities that individual churches may not be able to specialise in by themselves. These movements are characterised as Protestant, evangelical and ecumenical, focused on evangelism and social welfare, and of course focused on and specialist in methods of their activities. In order to understand them, their legitimacy should be argued from historical perspective more than from Scriptural perspective. Their critics lean towards scriptural and theological debate to deregulate them, whilst their proponents use historical and effectiveness to defend them. The historical proliferation of parachurches centres them in nodal dialogue as important partners in Christianity. The areas of tensions with the church are highlighted as those based on theology, finances, accountability, governance, and human resources. The reality of parachurches is irreversible. They make impact on South African Christianity by producing outstanding leaders that are currently in key positions in the civil service, churches and corporate world. An appeal is that the church and the parachurch should enter into dialogue with each other in order to find a common ground of how to advance the kingdom of God in the world wreathing in pain of oppression, poverty, unemployment, social stigmas, etc.

Intradisciplinary and/or interdisciplinary implications: This article is written from a personal experience and perspective. Almost three quarters of my ministry involvement is with the parachurch organisations. By reviewing the literature from church history and missiology and practical and systematic theology, it reveals the rationale behind tensions between church and parachurch organisations. These tensions are debated theologically and historically, and thus it is recommended that these two entities must draw a synergy by engaging dialogically in order to see how to complement each other.

Keywords: church; parachurch; theology; denomination; dialogue; ecumenical.

\section{Introduction and definition}

Although the historical sketch of the parachurch movements in this article focuses on North America, these movements at the same time flourished in Europe as well as in the developing countries. The article epitomises by giving some examples of South African experiences. The prefix 'para' means 'alongside of, by, or near'. Therefore, the term 'parachurch' means 'alongside of the church'. Some literature uses the term 'para-local church', but I prefer the term 'parachurch' in this article, and broadly to refer to any ministry structure other than a local congregation. Church history and mission studies conclude that parachurch movements include denominational structures, associational structures, seminaries, Bible schools, denominational mission agencies, independent mission agencies, as well as a multitude of relief, translation, evangelistic, discipleship, church service and other specialist agencies (White 1983:64). Therefore, parachurches can operate within or without denominational structures. The common feature is that they are identified or located within the church.

This article restricts itself to the definition of the parachurch as a Christian organisation that engages in social welfare and evangelism without restricting itself to a specific religious denomination. Parachurch organisations work outside and across denominations, and seek to come alongside the church and specialise in activities that individual churches may not be able to specialise in by themselves. They often cross denominational, national and international boundaries by providing specialised services and training. Some features that characterise parachurch organisations include business-like structures, non-profit corporations or, in some situations, private associations (groups of individuals who cooperate for a common goal). 
Most parachurch organisations born after fundamentalistmodernist controversy subscribe or affiliate to Protestant or evangelical faith; hence, the majority of them adopt the World Evangelical Fellowship's Statement of Faith made up of seven articles. Some of these organisations cater to a defined spectrum amongst evangelical beliefs, but most are selfconsciously interdenominational and many are ecumenical. In recent missiology, a parachurch organisation is called a sodality.

Ralph Winter, a well-known socio-missiologist, introduced the terms modality and sodality into missiology to refer to 'the Two Structures of God's Redemptive Mission' as a controlling mission paradigm. Modalities are the early parish churches, inherited from the Jewish synagogues. Sodalities are the missionary bands, the independent groups of missionaries that had little or no connection with the modalities which functioned as synagogues for the followers of Christ. Sodalities were a spontaneous innovation but echoed back to existing Jewish structures (Winter 1999:221). Modalities are organic structures rooted in particular soil. They are tied to particular social communities. They do not change and do not move. By contrast, sodalities expand, innovate and address mission in proactive, creative ways (Blincoe 2011:163). In all this analysis, denominations are modalities, and parachurches are the sodalities. The recent developments point to the fact that both can take two shapes, especially when coming to incarnational evangelism

The above definition reveals some salient features about the parachurch movements. Firstly, they are Christian - mostly Protestant or evangelical. People who join parachurch organisations normally do not have to sever ties with their Christian denomination. The work of the organisation is often seen as giving expression to a religious principle that may not be fully possible within the scope of one single denomination. Many such organisations are started by a core group of Christians who are associated with a given denomination, but open their membership to all Christians who identify with the mission statement and basic values of the organisation.

Secondly, their functions revolve around evangelism, empowerment and social welfare. This is their specific goal. They are in many ways not either-or, but conclusive and inclusive of these three pillars. The parachurch movements, especially after three quarters of the century of their existence, run their lives, mission and affairs around kerygma and incarnation. They believe in kerygmatic activities such as evangelism, discipleship, Bible studies, etc. On the other hand, they find it difficult to divide their kerygmatic responsibilities from diaconal responsibilities. Their congregational (koinonia) backgrounds dictate their modus operandi, which has been identified by Pali (2019:203) that '[ $p$ ]roclaiming the gospel of the kingdom of God and social involvement are not two separate mandates; they are intrinsically linked'. However, many, if not all, parachurches' mission is kerygmatic, diaconal or koinonia, and they emphasise the three, although sometimes with heavy leniency to one or two of the three. Therefore, their ministry may be 'that of proclaiming work of evangelism, the loving acts of service, and the patient building up of a fellowship, the church' (Kritzinger, Meiring \& Saayman 1994:129).

Thirdly, they are ecumenical. This means that they are transdenominational, interdenominational or nondenominational. They continue to define themselves as nonsectarian, and of course apolitical. Along with many worthwhile purposes, a parachurch organisation can also be a means of bringing together people who wish to promote a belief system that involves constructive purposes in the wider community. Since the inception of these groups, one's denominational affiliation had never been a stumbling block for involvement. The basic criteria are personal faith in the Lord Jesus Christ and passion to serve. This approach is one of the contributing factors to the growth and strength of the National Associations of Evangelicals or Councils of Churches. These two ecumenical streams attest their strength to the affiliated parachurch agencies. However, one needs to note that while some denominations readily identified with parachurches, other conservative churches distanced themselves from them. The Southern Baptist Convention and the Missouri Synod of the Lutheran Church are notable examples of this latter stance (Clowney 1996:22).

Fourthly, parachurches specialise in their ministries. A parachurch organisation can be built around any common set of values and goals. This means that it may focus on promoting the well-being amongst a gender, age group, economic group or race. At the same time, a parachurch agency may develop in response to a need present within a given community, such as assistance to the poor, or providing ongoing ministry to persons with mental disabilities. 'Parachurch groups can focus their entire attention on certain specific areas' (White 1983:17). They have been criticised by the broader church for ministering to select groups (children, youth, students, couples, elderly, disabled, singles, etc.) rather than to a broad spectrum. Criticism goes on to say that they give a narrow scope of God's work. On the other hand, the parachurch agencies identify and possess a passion for the areas neglected by the church, and focus on that area. Diversity is a hallmark of specialisation of these movements. Whilst the church is primarily generalist in its ministry, parachurches are narrowly specialist (White 1983):

Their plethora of specializations include personal and small group evangelism, church planting, mass evangelism, literature distribution, broadcasting, theological education, medicine, agriculture, relief, aviation, camping, communications, discipleship, fund-raising, management consulting, orphanages, translation, youth ministries, and a host of others. (p. 53)

According to Mathison (2014), they are often focused on one mission or purpose. There are parachurch organisations devoted to missions (e.g. Africa Inland Mission and United States. Center for World Mission), Bible distribution (e.g. Gideons and Bibles for the World), discipleship and evangelism (Navigators and Young Life), publishing 
(Crossway and Banner of Truth), various social services (crisis pregnancy centres, homeless shelters and food pantries), ministerial education (e.g. Reformed Theological Seminary and Westminster Theological Seminary), and many more. Ligonier Ministries is an example of a parachurch ministry with a primary focus on the theological education of laypeople.

Fifthly, they are non-profit making. This factor is re-enforced by these movements' reference to 'faith mission'. This term refers to a missionary organisation that encourages its missionaries to 'trust in God to provide the necessary resources'. Historically, faith missions did not pay their missionaries salaries; they were expected to depend on faith that God would provide for them. In practice, this came to mean that missionaries engaged in various activities to develop a financial support base. In the contemporary context, many parachurches pay regular salaries. These are raised through various means by the organisation. Conservatively speaking, a faith mission is when a mission board which is not related to any denomination does not receive its personnel and financial support from any denomination or church group. Since they are nondenominational or interdenominational, they are reputable for being well-organised with a long history of effective work and a reputable Christian service (Coggins 1975:77). Most, if not all, Christian workers involved in parachurch organisations do not receive their financial support from their own churches, but from individuals, other churches, friends and relatives, and from the corporate world. There are divergences in the methodologies of sourcing and accessing funds by these movements.

\section{Historical sketch of the parachurch movements}

The idea of a parachurch organisation has been around for at least two centuries. For instance, during the 19th century, abolitionist organisations that were not tied directly to one denomination provided a means for persons who were against slavery to unite their efforts without having to report to any one Christian church. Church historians and missiologists agree that many of the 19th century parachurch organisations proliferated as a by-product of the fundamentalist-modernist controversy. This controversy originated in the 1920s and the 1930s, especially within the Presbyterian Church of America. The controversy was exacerbated by foundational disputes regarding the role of Christianity, the authority of Scripture, death, resurrection and the atoning sacrifice of Jesus Christ (Longfield 1997). Evangelicalism broke out of the ghetto of fundamentalist isolation by making some compromises with the secular culture that made liberalism respectable, and redundant (Clowney 1996:22). Protestantism split into two branches as a result of this controversy. These were Fundamentalists who insisted upon the timeless validity of Christian orthodox doctrines. Cairns (1978:440-441) refers to them as a ReformedEvangelical Movement out of Revivals and Awakenings. The other branch was the Modernists who not only advocated for a conscious adaptation of religion in response to the new scientific discoveries and the moral pressures of the age, but also promoted complete union of churches. This, according to Cairn (1978:440-441), is what is currently known as Ecumenical Movement. The schism opened a huge gap that necessitated the birth and proliferation of the parachurch movements. These movements served to unite Christians in Bible-believing churches with one another and with fellowbelievers in mainline liberal denominations.

Revivals that led to the formation of parachurch movements did not aim at church unity, but mainly motivated by personal-religious ideas. These revivals created solidarity between believers, independent of nationality and denominational connections (Paas 2016:270). The debates amongst the parachurches do not revolve around dogmas, liturgy or polity. Debates are never on historical conceptions of the church or the validity of ecumenicity. For these people (Cairns 1978):

Any sound ecumenical movement must be built upon a unity of spirit, based upon an experience of Christ as Saviour from sin and upon the Bible as the fully-inspired, infallible source of faith and conduct. (p. 498)

During the early 20th century, parachurch organisations were formed for other purposes, such as providing relief in war-torn areas of the world or providing soup kitchens or other support during the American Depression. This article concentrates more on the second half of the 20th century, that is, the 1940s onwards, whilst using some movements that were started earlier than this period, in order to qualify the facts. Strommen (2001:31) pointed out that during this period, leaders of parachurch groups began appearing on the scene. The era is dubbed as that of evangelical entrenchment, a time when evangelical faith became 'isolationist and ineffective in their outreach' (White 1983:52). Many were disillusioned and impatient with the entrenched evangelical church establishment. Although the nodal origin was the United States of America, Europe was not left out (Wilson 1980):
A wave of Christian organisations rolled across the U.S. at the end of World War II. Energetic, visionary young men boarded DC-3s and crisscrossed continents. With evangelistic zeal and a sense of America's new leadership, they mounted a sort of spiritual Marshall Plan. They held large meetings, printed literature, made movies and sought out the needy and displaced peoples in former theatres of war. (p. 18)

The Christian movement has been caring for outcasts since the time of Christ. God's concern for the alien, the outcast and the helpless is central to biblical ethics in both the Old Testament and New Testament. Evangelical activism on behalf of people in crisis gained momentum in the mid-20th century as industrial societies created commercial enterprises and people were exploited for cheap labour, as they were victims of war. The devastations of the two World Wars left many homes without the father figures; and during the absence of the fathers, children, especially teenagers, found comfort on streets, not in churches. Parents grieved for the 
loss of their own carefree adolescents. The gap was opened for the emergence of the parachurch movements, which took evangelism to high schools and 'pioneered relational ministry as a means to disciple youth - technically alongside congregations' (Dean \& Foster 1998:211).

In the 21st century, the parachurches are an inevitable reality. Since their inception, churches had waged wars against them. These wars watered the parachurch roots to grow deeper and stronger. Almost $90 \%$ of what the church does is aided by the parachurch movements, starting from technological publications to external ministries. Church literature for Sunday Schools, Bible Studies, etc., are abundantly produced by the independent publishers. Campsites and conference centres used by churches are in majority run and owned by parachurch agencies. The television and radio networks are extensively owned by the parachurch organisations for the benefit of the church.

\section{Why the church and the parachurch are in conflict?}

It needs to be noted that historically some organisations that began as parachurch movements became denominations. For instance, Methodism as the parachurch movement sent out missionaries to countries but then found churches and/or denominations in the mission field. This is one of the historical records that developed some mistrust between the church and the parachurch.

Regardless of this record, an open-minded theologian or church leader always interrogates the question regarding the rationale behind the conflicts. People who are kingdomminded struggle to see why the two cannot dialogue together. However, here follows some reasons presented as to why the dialogue is barred, avoided or even justified.

\section{Theological argument}

It has been argued, for example, that there is no scriptural justification for parachurch ministries and that their very existence is inherently erroneous. The critics, who happen to be theologians, argue that Christ is building his church, not his parachurch. These theologians further claim that all the good things that parachurch ministries are doing can be and should be done under the oversight of the local church. Church leaders and their devotees argue against parachurches by using a biblical justification and theological legitimacy of the parachurch movements. White (1983) argues that parachurches can work with and within local churches to focus on needs that larger congregations and pastors lack time or gifts to address. His theological justification for parachurch groups, however, is noticed in congregational ecclesiology in which the local congregation is supreme. Those that share that ecclesiology are more likely to follow his derivative arguments than others. White (1983) is extensively quoted in this article because as an evangelical theologian he writes from the experience of extensive involvement with the parachurch (The Navigators), and later with the church. He has this to say (White 1983):

Theology rarely resolves conflict since most conflict in and among churches is seldom truly theological. Consequently, embarking upon a theological examination of local church and para-local church issues becomes almost futile. Since so many people react strictly from their own theological training or from a pragmatic position based on experience. (p. 63)

Criticism continues to argue that the Bible explicitly prescribes nothing about publishing companies, crisis pregnancy centres or theological seminaries. No description organisations labelled 'parachurch' exists today. For these critics, the Old Testament focuses primarily on God's covenant with the nation of Israel, wherein the various ordained functions of prophets, priests and kings were accomplished within the overarching context of the covenant people of God. The New Testament focuses on the coming of the Messiah, the inauguration of his kingdom and the establishment and early growth of his church.

Theological debates of the definition escalated into seeing the marks of the church as visible and invisible. These marks encapsulate the broad definition that the church has a visible form, that is, it is organised on earth as an observable society (Clowney 1996:108). The visible church is clearly identified by its organisation and structure (liturgy, confessions, polity and sacraments), whilst the invisible church is composed of all the converted people, known or unknown. The debate is how are the parachurches the visible or invisible church? Those embracing the 'visible church' notion write off the parachurches, whilst those of 'invisible church' embrace the parachurches as the invisible church is bigger than what is visible (church on earth). The balanced approach is that the visible church is glorious insofar as it resembles the invisible church. 'Visibility and invisibility are the two aspects of the one church of Jesus Christ' (Kuiper 1998:29).

Parachurch agencies and their relationship with the church were discussed at the Lausanne Congress on World Evangelization in 1974. Snyder (1983) highlighted in the Introduction of the Document of that Congress points that the church and the parachurch need to understand each other. The argument in favour of parachurch organisations is largely historical, namely, that under God they have made a much greater contribution to world evangelisation than the church has done. This is indisputable. The contrary argument begins with Scripture rather than history, asserts that only the Church can claim to be a divine creation and concludes that ideally the church should itself undertake necessary specialist tasks. It is not easy to reconcile these appeals to history and Scripture, to reality and to the ideal. I associate myself with Cunningham, De Colle and Lamadrid (1999:192) that Christian theologians, especially evangelical ones, need desperately to make ecclesiological sense of parachurches because if the parachurch model remains unintelligible to theologians, theologians will remain unintelligible and uninteresting to most Christians. The bottom line is the 
parachurch cannot be ignored, nor can the parachurch ignore the church.

After all these theological arguments, the balanced view is that 'taking the initiative to engage the issue of the parachurch from the perspective of one's theology makes possible a proactive ministry' (Phillips 1991:119).

\section{Financial argument}

Regarding finances, a question is always, 'generosity and giving is important and biblical, as a Christian, is giving to a religious organisation or parachurch the same as giving to a local church?' Those who are on the opposition benches against the parachurches always express that a parachurch organisation is not a church and should not act like a church as it is not a ministry of a church.

The fire is stoked by the fact that parachurches run like modern corporate culture which values efficiency, risk management, clean organisational structures and a strong financial ledger. As a result, many parachurch organisations place a high value on what raises the most money, minimises risk or produces the most efficient management structure. This has become a basis for criticism that parachurch ministries need an understanding of management and money that runs counter to worldly culture (Stiles 2011).

In all organisations - secular or religious - money stirs emotions. It divides friends, families and churches. Yet it is a necessity for livelihood, for as the scripture says: and money is the answer for everything (Ec 10:19b). Some local church pastors have complained that the money given to parachurch ministries should be given to the local church. They claim that parachurches siphon off contributions that are legitimately theirs. Theology of tithing built around Malachian concept of storehouse tithing (Mal. 3:8-10) becomes an appeal to disqualify parachurches' access to church finances. The fact is that the high percentage of parachurches' finances comes from individuals, and not from churches. This escalates competition between these two entities, especially in severe economic crises. Radmacher (1978) says:

The support of these organisations interferes with the necessary financial backing for the local church, necessitates the redirecting of valuable time that should be spent in Christian service through the local church, and destroy a proper loyalty to the local church. (p. 189)

\section{Accountability argument}

Another major concern is the potential lack of accountability in parachurch organisations. This argument is intertwined with the financial one. Some church leaders become concerned to see how donors express their preference towards parachurches than local churches. They see this as empowering parachurches to do what they like without accounting to anyone. Church leaders continue to complain about the inexperienced youngsters climbing the ranks of leadership without any solid grounding on ethics of accountability. Some pastors are convinced that any leadership structure outside the church is illegitimate (White 1983:25). On the other hand, parachurch people feel rejected and forsaken by their own churches, and therefore see no reason to account to them. They feel that they are the rejected missionaries, and so prefer to swim on their own, and account only to their supporters and donors.

\section{Governance argument}

In many discussions concerning parachurches, the issue of governance is never left out. Whilst the organised church clearly defines its polity to be episcopal, Presbyterial or congregational, the ecumenical composition of the parachurches does not organise or structure them along those lines. They may be regarded as irregular in denominational polity, although not sectarian in violation of the New Testament governance principles. Corporate culture and structure are routinely imported into parachurch ministry leadership. They operate and conduct their operations by borrowing structures from business corporations, sometimes from the military structures. The founder of the organisation normally becomes the Chief Executive Officer or the Commander-in-Chief (Clowney 1996:24, 107). It is of great interest to observe that currently many, if not all, of the modern charismatic megachurches structure themselves along the corporate lines. They are run like businesses, and register their entities with governments as close corporations. This might justify the fact that the parachurches are on the cutting edges of communities' sociocultural realities, therefore influencing the church polity in some ways.

\section{Human resource argument}

As White (1983:31) highlights, ‘[e]very ministry has its major commodity - people. And of these people, leaders are always at a premium'. The church and the parachurch fish from the same pond - financially and human power. The grievance by the church is that parachurches remove people who could help meet church needs. These organisations possess potentials to drain leadership from local churches, and therefore become exclusive and manifest a superior attitude (White 1983:25). This is always a source of conflict.

\section{Impact of parachurch movements on South African Christianity}

Like in North America, Europe and elsewhere, the parachurches are found everywhere in South Africa. Studying them, one could realise that they are in two streams - the international ones, that is, those who were birthed overseas and were imported to South Africa; and the indigenous ones, that is, those who were pioneered here and grew locally or externally (e.g. Healthcare Christian Fellowship, South African General Missions, etc.). Parachurches are operational in communities, centres of learning, healthcare centres, correctional centres or limitedly in churches. In South Africa, these movements are known for their radical stances on 
issues of social injustices or symbiotic relationships with the status quo, which is beyond the scope of this article to expatiate on.

Many South Africans, black and white people, during the apartheid era, whenever rejected by their denominations, took shelter under and through the parachurch formations. For instance, Beyers Naude, after being abandoned by his own Dutch Reformed Church for his social conscience against racism, launched an ecumenical publication, Pro Veritate in 1960 and organised a non-racial, ecumenical Christian Institute of Southern Africa in 1963 (Walshe in Elphick \& Davenport 1997:387).

Dr Louw Alberts, the renowned scientist and devout Christian was a Dutch Reformed devotee, but led a parachurch named Youth for Christ International/South Africa for 33 years. He was unashamedly evangelical and believed in evangelical conscience of righteousness that comes by conviction of the heart. He was marked to co-lead the famous Rustenburg Conference initiated by F.W. De Klerk 'to draw together as wide a spectrum of opinion as possible' (Walshe in Elphick \& Davenport 1997:397), in seeking the equitable way forward for the new South Africa that was on a horizon.

Centres of learning, especially high schools, colleges and universities, were platforms on which parachurches such as the Student Christian Movement (SCM) articulated their theological sanities and leadership honing. It is out of formations such as Youth for Christ, Scripture Union (SU), Campus Crusade for Christ International, Youth Alive and University Christian Movement that today the church, society and corporate world enjoy the seasoned and sharpened leadership. South Africans hear every now and then that the current State President Matamela Cyril Ramaphosa is a product and was an active member of SCM. In his early life as a law student in the 1970s at the then University of the North, colloquially known as Turfloop University, and now known as the University of Limpopo, Ramaphosa was the leader of the SCM. The SCM was weak and seen by some as a tool of domination. Ramaphosa worked tirelessly with Frank Chikane and others to turn it into a vibrant organisation. For him religion, or more precisely black theology, became the rallying point, or a political fulcrum, from which to launch a rebellion against an apartheid state that had heightened its oppressive programmes. Ramaphosa, through the SCM, was part of the burgeoning group of students prosecuting the liberation struggle from the black consciousness perspective, and the SCM was its integral part (Mdhlela 2018).

One of the heroes of liberation in South Africa is Rev Frank Chikane, who once worked as a Director General in Presidency in the democratic South Africa. Like Ramaphosa, Frank's honing into skilful and ethical leadership can be attributed to his extensive involvement with SCM (VillaVicencio 1996):
Arriving as a student at the University of the North, Chikane joined the Student Christian Movement (SCM) and later the South African Student Organisation (SASO). Within this context theological debate intensified. He recalls reading a paper on Christianity and Black Consciousness. 'Black theology, as far as I was concerned, provided the answer to all my questions; and I still regard the black theology debate as the most important theological debate ever to have taken place in South Africa. We cannot, however, deify or absolutise any system of thought,' he insists. 'God is a disturbing and destabilising God, constantly requiring us to be shaken out of our self-complacency and theological contentedness'. (p. 71)

One opposition party in parliament is African Christian Democratic Party, led by Rev Kenneth Meshoe. He and his wife, Lydia, are some of the stalwarts of SCM at Turfloop. Both being teachers, they are also talented musically. They were closely associated with Christ for All Nations (CfAN), a parachurch and evangelistic outreach pioneered and led by the German evangelist Reinhard Bonnke. This parachurch organisation, although interdenominational, had a strong symbiotic relationship with Apostolic Faith Mission (AFM). Historically, black Pentecostalism in the AFM showed a remarkable theological and phenomenological similarity to the developing independent black Zionist movement until the 1950s and the 1960s (Mofokeng \& Madise 2019:2). Christ for All Nations played a major role of pushing this denomination out of African Zionism into classical Pentecostal Church. This liberal proclivity was only amongst the 'Bantu' Apostolic Faith Mission, and Bonnke's ministry in South Africa left some indelible marks of reviving and revolutionising AFM.

One of the vibrant, articulate, witty young politicians in South Africa is a recent leader of the official opposition party, Democratic Alliance, Mmusi Aloysius Maimane. Whilst doing Grade 8, he attended a SU Camp, a very strong parachurch movement working in schools. It was at this camp that Maimane had to make an informed decision to convert from Catholicism to evangelicalism. He highlighted in a Scripture Union Magazine, 'I realise this camp resulted in my decision to follow Jesus ...' (Maimane 2007:n.p.). It was through this parachurch organisation that he was exposed to multi-cultural interactions - the experiences that even led him to cross the race bar. In this magazine he continued, '... [i]t gave a cross-cultural experience that was very limited in the 1980s, which subsequently made white people "okay" in my eyes' (Maimane 2007:n.p.). Msomi (2016) confirms that:

It was also through SU that Maimane began his involvement with the NGO sector, especially focusing on youth development. He started working as a volunteer for SU West Rand when he was in Grade 12 and ended up being one of the organisation's director in that region. (p. 69)

Sitting around the SU talks, the name of Maimane will crop up spontaneously as a man governed by ethics of hard work, integrity and moral fidelity. He once highlighted that the impact that SU had made upon his life has been more 
far-reaching than what he himself did for the organisation (Maimane 2007:n.p.). Within the first few days after arrival in parliament, Maimane disclosed as part of interest disclosure that he is a member of the Board of Directors of a parachurch called Youth for Christ - another parachurch that has left indelible impact on South African Christianity. The man is closely associated with parachurch ministries more than the organised denominational Christianity. For instance, he is also a part of Change Agents, Heartlines, Child in Crisis Foundation, Siyakholwa Development Foundation and New Africa Foundation (Msomi 2016:69).

If it was possible to identify the impact of parachurches in South African civil society, corporates and churches, and the list will be endless. One needs to record that like in North America and elsewhere, the church and parachurch tensions in South Africa is an anathema to live with. The parachurch fruits of labour were and are not always recognised by the church, regardless of the analogy that parachurches preach a pumpkin gospel. They plant and water (evangelism and discipleship) this side and the pumpkin climbs the wall and bears fruit next door, which is normally the church. "The "usversus-them" mentality still exists, but it's got to go' (Moring 1997 in Dunn \& Senter III 1997:573).

\section{Conclusion}

One of the inspiring shifts and theology as well as in church praxis is the wide acceptance of the church being a missional church. The church is called to join the Triune God in his mission in the world. The church is regarded not only as the denominational structure, but also as the body of believers working in the world wherever they are. In missional theology, the sharp division between the church and parachurch is disappearing. The parachurch is church! Unlike before, there are currently some symbiotic relationships between the churches and the parachurches, although dialogue is still needed to enhance missional cooperation.

The reality of parachurches is irreversible. Theology of the church is open to dialogues on the expansion of the definition of the church. There should be some synergy whereby the local churches should see parachurches as their hands to do and feet to go where they cannot go (Lawson \& Choun 1992):

Parachurch groups must not be perceived as 'additions' to the church nor 'usurpers' of the church. They are partners, working alongside the church. (p. 172)

Parachurches exist not for competition but for complementing the church. Churches that fear that parachurches leech donations from the church coffers or recruit workers from the church's volunteer base have a narrow perspective of kingdom mentality. No local church, no matter how economically viable it may be, can expect to reach all the needs in the community. On the other hand, parachurch people need to hang out in the church to really know and understand what the church needs.
An appeal is that the church and the parachurch should enter into dialogue with each other in order to find the common ground of how to advance the kingdom of God in the world wreathing in pain of oppression, poverty, unemployment, social stigmas, etc. The church in South Africa and abroad should foster and sustain a constructive conversation across the denominational boundaries. The Moses' attitude at Mount Horeb should be the same: I will go over (closer) and see the strange sight - why the bush does not burn up (Ex 3:3), for there is a God in the strange vision of the burning bush. Instead of carnivorously tearing each other apart, the two entities must come closer to each other in order to understand. They must come closer to hear the clarity of the mandate, which is the deliverance of the oppressed people whose cries had reached the heart of God. Proper theology dialogues, engages and interrogates in order to gain perspective, not to create the walls of hostility. That is the essence of theology of dialogue. Lyimo (cited in Wabanhu \& Moerschbacher 2017:209) agrees with Orobator (2008:xi) that theology is a conversation, a discourse, a dialogue and a communication in matters of daily life experience and faith. The church and the parachurch should create a dialogue that is centred on reconciliation, peace and justice. They should become dialoguing partners in order to engage in the reflecting work of faith that seeks understanding (Benedict XVI 2011).

It is possible that the church and the parachurch can dialogue in order to agree. Dialogue is a true locus theologicus - a proper place for theologising the synergy between these two entities. Ongoing dialogical deliberations unfold some further and deeper experiences that sustain a faith dialogue in terms of seeking understanding. Dialogues help partners to enter the realm and experience of others in such a way that they help change mindsets from misconceptions to appreciations.

\section{Acknowledgements Competing interests}

The author has declared that no competing interests exist.

\section{Author's contributions}

I declare that I am the sole author of this research article.

\section{Ethical consideration}

This article followed all ethical standards for research without direct contact with human or animal subjects.

\section{Funding information}

This research received no specific grant from any funding agency in the public, commercial or not-for-profit sectors.

\section{Data availability statement}

Data sharing is not applicable to this article as no new data were created or analysed in this study. 


\section{Disclaimer}

The views and opinions expressed in this article are those of the author and do not necessarily reflect the official policy or position of any affiliated agency of the author.

\section{References}

Benedict XVI, 2011, Post-synodal Apostolic Exhortation Africae Munus: The Church in Africa in service to reconciliation, justice and peace (19 November 2011), Libreria Editrice Vaticana, Vatican

Blincoe, R.A., 2011, 'Relating church hierarchies to mission agencies: Healing a breach in the Protestant Church', in B. Snodderly \& A. Scott Moreau (eds.), Evangelical and frontier mission perspectives on the global progress of the Gospel, pp. 163-180, Regnum Books, Oxford.

Cairns, E.E., 1978, Christianity through the centuries, Zondervan Publishing House, Grand Rapids, MI.

Clowney, E.P., 1996, The Church: Contours of Christian theology, InterVarsity Press, Downers Grove.

Coggins, W.T., 1975, So that's what missions is all about, Moody Press, Chicago, IL.

Cunningham, D.S., Del Colle, R. \& Lamadrid, L., 1999, Ecumenical theology in worship, doctrine, and life: Essays presented to Geoffrey Wainwright on his sixtieth birthday, Oxford University Press, New York, NY.

Dean, K.C \& Foster, R., 1998, The godbearing life: The art of soul-tending for youth ministry, Upper Room Books, Nashville, TN.

Dunn, R.R. \& Senter III M.H (eds.), 1997, Reaching a generation for Christ, Moody Press, Chicago, IL.

Elphick, R \& Davenport, R. 1997, Christianity in South Africa: A political, social \& cultural history, David Philip Publishers, Cape Town.

Kritzinger, J.J., Meiring, P.G.J. \& Saayman, W.A., 1994, On being witnesses, Orion Publishers, London.

Kuiper, R.B., 1998, The glorious body of Christ, The Banner of Truth, Edinburgh.

Lawson, M.S \& Choun, Jr. R.J., 1992, Directing Christian education; The changing role of the Christian education specialist, Moody Press, Chicago, IL.

Longfield, B.J., 1997, 'For church and country: The fundamentalist-modernist conflict in the Presbyterian Church', The Journal of Presbyterian History 78(1), 35-50.

Lyimo, D.E., 2017, The task of African theology for the church in Africa today: A Theological Discourse between the Academy, Narratives, and Africae Munus', in E. Wabanhu \& M. Moerschbacher (eds.), The shifting ground of doing theology: Perspectives from Africa, pp. 208-219, Paulines Publications Africa, Nairobi.

Maimane, A., 2017, SU impacted my life, viewed 16 March 2017, from http://www. su.org.za/downloads/magazine/SU360-July07.pdf.
Mathison, K.A., 2014, 'Evangelism and Missions, the Church', Tabletalk Magazine 01 September, viewed 22 March 2020, from https://www.ligonier.org/learn/ articles/historical-and-theological-foundations/.

Mdhlela, J.M., 2018, Ramaphosa gets to the bones of it with biblical texts, viewed 26 March 2020, from https://www.sowetanlive.co.za/opinion/columnists/2018-0313-ramaphosa-gets-to-the-bones-of-it-with-biblical-texts/.

Mofokeng, T. \& Madise, M., 2019, 'The Evangelicalisation of Black Pentecostalism in the AFM of SA (1940-1975): A turning point', Studia Historiae Ecclesiasticae 45(1), 16p. https://doi.org/10.25159/2412-4265/4050

Moring, M., 1997, 'Church/Parachurch: How can they work together in youth ministry?', in R.R. Dunn \& M.H. Senter III (eds.), Reaching a generation for Christ, pp. 563-574, Moody Press, Chicago, IL.

Msomi, S., 2016, Mmusi Maimane: Prophet or puppet?, Jonathan Ball Publishers, Johannesburg.

Orobator, A.E., 2008, Theology brewed in an African pot, Orbis Books, New York, NY.

Paas, S., 2016, Christianity in Eurafrica: A history of the church in Europe and Africa, Christian Literature Fund, Wellington.

Pali, K.J., 2019, 'The role of ministers in community development: The DRCA OFS as a case study', Acta Theologica 39(1), 200-221. https://doi.org/10.18820/23099089/ actat.v39i1.10

Phillips, R.J., 1991, 'The Officer's Christian Fellowship: An inquiry and evaluation', in G.E. Tyson (ed), Military Chaplain's review, Volume 165 of DA Pam, pp. 115-125, University of Virginia: Chaplains, US. Army.

Radmacher, E.D., 1978, What the church is all about, Moody Press, Chicago, IL.

Snyder, H.R., 1983, Cooperating in world evangelization: A handbook on church/parachurch relationships (LOP 24), Lausanne Occasional Paper 24, viewed 22 March 2020, from https://www.lausanne.org/content/lop/lop-24\#appb.

Stiles, J.M., 2011, Nine marks of a healthy parachurch ministry: Church and parachurch: Friends or foes?, viewed 26 March 2020, from https://www.9marks. org/journal/church-and-parachurch-friends-or-foes/ 03.01.2011.

Strommen, M., 2001, 'A recent invention: The profession of youth ministry', in M. Strommen, K.E. Jones \& D. Rahn (eds.), Youth ministry that transforms: A comprehensive analysis of the hopes, frustrations, and effectiveness of today's youth workers, pp. 27-40, Youth Specialties Books, Zondervan Publishing House,

Villa-Vicencio, C., 1996, The spirit of freedom: South African leaders on religion and politics, pp. 62-75, University of California Press, Berkeley, viewed 27 March 2020, from http://ark.cdlib.org/ark:/13030/ft4p3006kc/.

White, J., 1983, The church and the parachurch: An uneasy marriage, A critical concern book, Multnomah Press, Portland.

Wilson, R., 1980, 'Para-church: Becoming part of the body', Christianity Today, 19 September, pp. 18-20.

Winter, R., 1999, 'The two structures of god's redemptive mission', in R.D Winter \& S.C. Hawrhorne (eds.), Perspectives on the World Christian Movement: A reader, 3rd edn., William Carey Library, Pasadena. 